\title{
THE INFLUENCE OF SURFACE COATINGS ON THE TOOTH TIP DEFLECTION OF POLYMER GEARS
}

\author{
VPLIV POVRŠINSKIH PREVLEK NA POVES VRHA ZOBA \\ POLIMERNIH ZOBNIKOV
}

\author{
Boštjan Trobentar ${ }^{1}$, Srečko Glodež1, Jože Flašker ${ }^{1}$, Boštjan Zafošnik ${ }^{2}$ \\ ${ }^{1}$ University of Maribor, Faculty of Mechanical Engineering, Smetanova ulica 17, 2000 Maribor, Slovenia \\ ${ }^{2}$ Prometheus, Boštjan Zafošnik s.p., Tacenska cesta 125 E, 1000 Ljubljana, Slovenia \\ bostjan.trobentar@gmail.com \\ Prejem rokopisa - received: 2015-03-09; sprejem za objavo - accepted for publication: 2015-07-29
}

doi:10.17222/mit.2015.056

When designing gear drives made of polymer, the tooth tip deflection is a crucial parameter in respect to the proper gear drive operation. Excessive tooth tip deflection can lead to serious disturbances of gear meshing and consequently to increased noise and wear of the teeth flanks. In such cases the tooth tip deflection can be reduced through the use of stiff surface coatings on the tooth flanks. In this paper the influence of different coating materials and thicknesses on the tooth tip deflection of polymer gears is analysed using comprehensive finite element computational analysis. The numerical results obtained are then used to define an approximate equation for the calculation of gear tooth tip deflection for the coating material used and the thickness of the surface coating layer. The results show that the tooth tip deflection decreases with large values of the coating material Young's modulus and with the coating layer thickness.

Keywords: polymer gears, surface coatings, tooth deflection, numerical analysis

Pri konstruiranju zobniških dvojic s polimernimi zobniki je poves vrha zoba zobnika eden ključnih dejavnikov, ki vpliva na pravilno delovanje zobniške dvojice. Prevelik poves vrha zoba namreč vodi do resnih motenj pri ubiranju zobniške dvojice, kar povzroči večji hrup in tudi večjo obrabo zobnih bokov. V takšnih primerih lahko poves vrha zoba zobnika zmanjšamo z uporabo togih površinskih prevlek. V predloženem prispevku je predstavljena obsežna numerična analiza po metodi končnih elementov, ki zajema vpliv materiala trde prevleke in debeline prevleke na poves vrha zoba zobnika. Numerični rezultati so nato uporabljeni za določitev aproksimativne enačbe za izračun povesa vrha zoba zobnika v odvisnosti od izbranega materiala prevleke in njene debeline. Končni rezultati kažejo, da se poves vrha zoba zmanjšuje z večanjem modula elastičnosti prevleke in debeline utrjenega površinskega sloja zobnih bokov.

Ključne besede: polimerni zobniki, površinske prevleke, poves zoba, numerične analize

\section{INTRODUCTION}

The primary function of gears is to transmit rotary or linear motion. The design for the kinematics of a gear set is geometrically controlled when the deflections of gear teeth during the gear drive operation are taken into account. Therefore, the selection of appropriate gear material is crucial in the design process. Recently, the development of new materials and technologies have resulted in increased use of engineering polymers for machine elements (e.g. gears) due to benefits such as low cost for injection moulding, light weight, resilience and their ability to operate under dry, unlubricated conditions. ${ }^{1}$ Polymer gears, when used in moderate power transmission applications without lubrication may have potentially conflicting tribological properties (low friction, high resistance to wear) and mechanical properties (stiffness, fracture strength). This situation is further complicated by the complex loading and contact phenomena that change throughout the meshing cycle. As the transmissible power levels increase, problems of surface temperatures arise due to the frictional losses between mating gear teeth. ${ }^{2,3}$
Most of these coatings are based on zinc and aluminium, which are mainly used for radio frequency shielding and electrical conductivity where the mechanical properties of the coatings are not of prime importance. The use of polymer with good strength to weight ratio as a base material is an alternative to metallic components. The main disadvantage is the poor wear resistance of contact surfaces. Recent research work regarding these problems has indicated that thermal spray coatings on polymers can be applied in many engineering applications. Careful selection of material combinations and the use of special process parameters can produce relatively thick metal, ceramic or carbide coatings which can be machined or ground. ${ }^{4}$

It is very important to optimize the gear design before the tools for manufacturing and experimental testing are made to decrease their cost. Traditionally, the gear designer had a limited number of analytical tools as well as his own experience to achieve this goal. Some of the most well known analytical tools for the prediction of gear tooth strength are the procedures according to ISO, VDI and AGMA standards..$^{5-7}$ As noted earlier, the tooth tip deflection becomes important for gears made of 
materials with low stiffness (e.g. polymers) as it can lead to disturbances in gear meshing in the case of excessive tooth tip deflection. The procedure of gear meshing considering the deflection effect is described in the VDI 2736 standard, ${ }^{7}$ where spur gear tooth tip deflection is influenced by the force, tooth face width and material stiffness, which is represented by the Young's modulus and the gear geometrical parameters. It is known that the Young's modulus of polymer materials is much smaller than that of steels, which are often used as gear materials. Furthermore polymer stress-strain behaviour is also affected by changes in the temperature.

Lately, thermoplastic polymers are widely used in manufacturing polymer gears. They have different stress-strain behaviour in the tensile than in the compression region which leads to different values of the Young's modulus in both regions. Furthermore, polymers can also show nonlinear behaviour in the elastic region which cannot be described with a Young's modulus. Therefore, the different stress-strain behaviour in tensile/compression regions and the nonlinear behaviour in an elastic region have to be described with an appropriate constitutive model using an appropriate computational approach (e.g. Finite Element Method). P. Wyluda and V. Wolf ${ }^{1}$ performed an elastic-plastic finite element analysis of meshing of two acetal copolymer spur gears under quasi-static loading conditions. Their computational results were in a relative good agreement with the experimental data. The effect of PTFE on the tribological behaviour of polymers in rolling sliding contact has been investigated for two of the most widely used polymers PA 66 and polyacetal. The experimental results showed that the friction and wear performance of the PTFE filled polymers was superior to that of the unfilled polymers. In addition, the surface cracking found in unfilled PA66 and thought to be responsible for the premature fracture of components such as gear teeth was suppressed by the PTFE. It is suggested that a combination of high surface temperature and high surface tensile stress, produced by friction, is required to initiate these cracks and that PTFE inhibits crack formation by reducing friction. ${ }^{8}$

In general, the gear tooth tip deflection can be decreased using a stiffer material with higher Young's modulus. If a gear is made of low stiffness material (e.g. polymer) the gear tooth stiffness can be increased using a stiff surface coating. Because the standard VDI procedure for the determination of gear tooth deflection includes only homogenous material properties, it is not possible to determine the deflection of a coated gear tooth using the equations available in the above quoted standards. ${ }^{7}$ For this reason, an appropriate computational model to analyse the tooth tip deflection of coated polymer spur gears with different coating materials is presented in this paper.

\section{MATERIALS AND METHODS}

Polymer materials have low stiffness that can lead to greater deflection of elements made of such materials. Excessive deflection can lead to serious problems in the meshing of polymer gears and consequently the additional loading of the gear teeth. According to the VDI $2736^{7}$ the deflection of the tooth tip of a spur gear in the circumferential direction can be approximately calculated from Equation (1):

$$
\lambda=\frac{\frac{F_{\mathrm{t}}}{\mathrm{b}}}{\frac{2 E_{1} E_{2}}{E_{1}+E_{2}}} \frac{E_{\text {steel }}}{c}
$$

where $F_{\mathrm{t}}$ is the tangential force in $\mathrm{N}, b$ is the face width in $\mathrm{mm}, c^{\prime}$ is the maximum tooth stiffness per unit face width (single stiffness) of a tooth pair in $\mathrm{N} / \mathrm{mm} \times \mu \mathrm{m}^{2}$, $E_{\text {steel }}$ is the modulus of elasticity of steel $\left(E_{\text {steel }}=210000 \mathrm{MPa}\right)$ and $E_{1,2}$ are the elastic modulii of gears 1 and 2 in $\mathrm{MPa}$ at room temperature. The maximum tooth stiffness per unit face width can be expressed in the Equations (2) and $(3)^{6}$ :

$$
\begin{gathered}
c^{\prime}=c_{t h}^{\prime} \cdot C_{M} \cdot C_{R} \cdot C_{B} \cdot \cos \beta \\
c^{\prime}{ }_{t h}=\frac{1}{q^{\prime}}
\end{gathered}
$$

Equation (2) uses the theoretical single tooth stiffness $c^{\prime}$ th as given by Equation (3), where $q$ ' is the minimum value for the flexibility of a gear pair. Individual factors in Equation (2) can be determined as described in the ISO 6336 standard: $C_{\mathrm{M}}$ is the correction factor that takes into account the difference between theoretical and actual values for solid disc gears $\left(C_{\mathrm{M}}=0.8\right.$ according to the standard ISO 6336); gear blank factor $C_{\mathrm{R}}$ takes into account flexibility of gear rims and webs $\left(C_{R}=1.0\right.$ for a solid disc according to the standard ISO 6336); the factor $C_{\mathrm{B}}$ reflects the influence of deviation from the gear basic rack profile according to standards ISO 6336 and ISO 53. 6,9

The deflection of the tooth tip $\lambda$ determined with Equation (1) must be smaller than the estimated permissible deformation $\lambda_{\mathrm{P}}=0.07 \cdot m_{\mathrm{n}}$, where $m_{\mathrm{n}}$ is the normal module in $\mathrm{mm}$. Overcoming of the permissible deflection $\lambda_{\mathrm{P}}$ can lead to serious disturbances of the meshing gear teeth and consequently to higher noise and a shorter service life of the gear pair. ${ }^{7}$

As mentioned above, Equation (1) cannot be used for calculation of the tooth tip deflection of coated gears. Therefore, an appropriate numerical model should be used in that case. The first step in developing a numerical model for the simulation of tooth tip deflection of coated gears was the creation of a numerical model that will yield proper results to be verified by analytical or experimental solutions, or solutions taken from standardised procedures. For this purpose a two dimensional 
plane strain model with homogeneous material properties (Hooke's law) and static load was generated. The stress-strain behaviour of the polymer material used in this paper consists of linear and non-linear regions (Figure 1). The assumption of using Hooke's law for polymer gears was verified by comparison of the tooth tip deflections based on material models that consider linear elastic material properties.

The static load used in the present model is based on the assumption that the number of loading cycles during the service life of the gear is small and that the gear is used only for partial rotation (e.g. application of the four bar mechanism and for slow motion of the gear rack). This is necessary due to the presence of polymer hysteresis during loading and unloading. If the material is viscoelastic, the path of loading is not coincident with the path of unloading, which occurs when the material changes significantly in volume and is experiencing large deformations. Furthermore, it is assumed that there is enough time for strain recovery and a permanent set effect of the polymer can be neglected. ${ }^{11}$

An accurate two-dimensional model of the benchmark gear was developed and imported into the ABAQUS software. The contact position of engaging gear tooth flanks was chosen to be on the outer point of single engagement, where the bending load is highest. Contact between engaging teeth was prescribed as a standard surface to surface contact, with the master surface set on the driving gear and the slave surface on the driven pinion gear. Assuming good lubrication, contact interaction was modelled as tangentially frictionless with finite sliding with no adjustments or smoothing between the surfaces. The influence of coating wear during the service life and consequently its influence on tooth toughness and deflection were not considered.

The pinion in Figure 2a was fully constrained in the centre bore, while displacements were only constrained in the gear, and the rotations remained free. The load was applied by torque load in the centre of the gear.

The material properties of the pinion were defined as hyper-elastic in the core and as linearly elastic in various coatings. The mesh was generated with CPS4R-type elements with locally controlled element size at tooth flanks (Figure 2b) and with at least ten elements in the

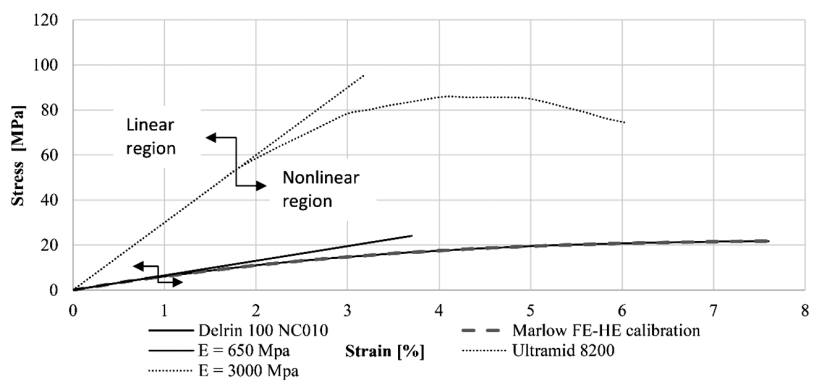

Figure 1: Material properties of pinion core ${ }^{10,11,13}$ Slika 1: Materialne lastnosti jedra pastorka ${ }^{10,11,13}$

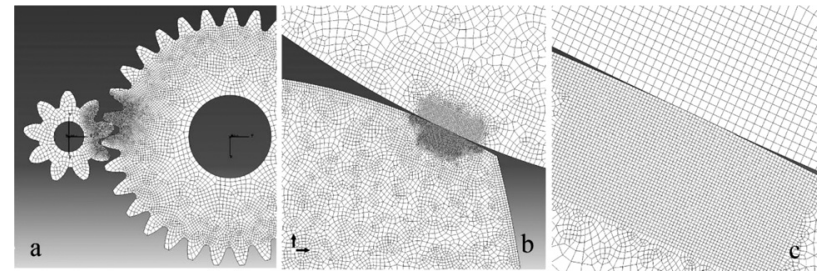

Figure 2: a) Numerical model, b) locally adjusted mesh on gear teeth and c) coating model on pinion

Slika 2: a) Numerični model, b) lokalna zgostitev mreže na zobu in c) prikaz sloja na pastorku

coating layer thickness direction (Figure 2c). The numerical model was also tested for convergence analysis. Figure 3 shows a significant improvement when the number of elements in contact was increased from 467 to 3456. An increase to 5538 elements had no influence on the results or calculation time.

Our workflow was combined from several steps. First, the gear deflection according to VDI $2736^{7}$ and ISO $6336^{6}$ standards are calculated. The analysed gears (gear and pinion presented in Table 1) have properties of the steel and the polymer material. Young's modulus and Poisson's ratio for the steel gear was $E=206000 \mathrm{MPa}$ and $v=0.33$, respectively, while the polymer material was described with the properties for POM (Figure 1) and $v=0.35$. A reference tooth tip deflection was calculated according to Equation (1). In the next step, a model with a coated polymer gear was generated. The pinion gear was partitioned between a coating layer (Figure 2c) and core material. Different models were created for different types of coatings and their thicknesses. Two different core material properties from DuPont and BASF (POM Delrin $100 \mathrm{NC}^{2} 10^{12}$ and PA Ultramid ${ }^{\circledR}$ $8202^{13}$ ) and several different materials used for coating

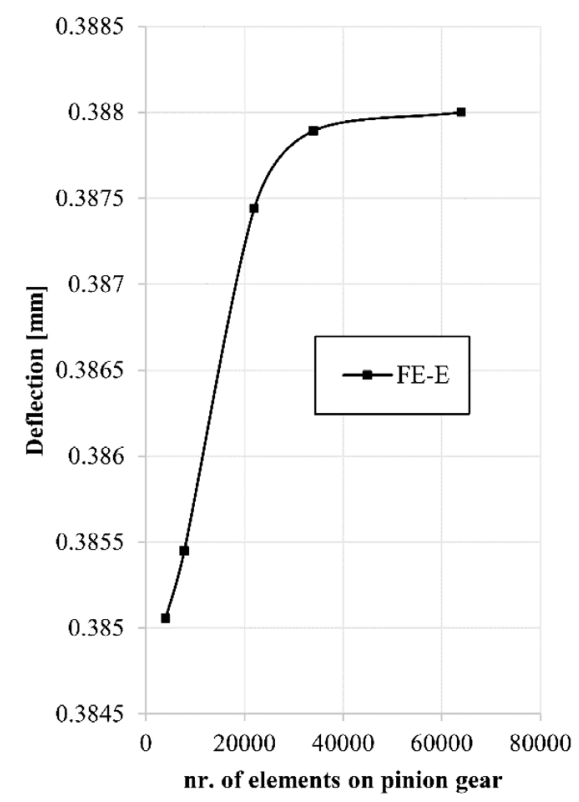

Figure 3: Mesh converge of pinion gear

Slika 3: Konvergenca mreže pastorka 
were studied; Polytetrafluoroethylene - PTFE $(E=560$ $\mathrm{MPa})$, aluminium - $\mathrm{Al}(E=70 \mathrm{GPa})$, Boron nitride $\mathrm{BN}(E=33.85-85.91 \mathrm{GPa})$ and Molybdenum disulphide $-\mathrm{MoS}_{2}(E=210-400 \mathrm{GPa})$ with various Young's modulii between $560 \mathrm{MPa}$ and $210 \mathrm{GPa} .{ }^{14}$ Four different thickness of the coating were modelled on the pinion: $t=$ $25 \mu \mathrm{m}, 50 \mu \mathrm{m}, 75 \mu \mathrm{m}$ and $100 \mu \mathrm{m}$.

Table 1: Details of gear pairs

Tabela 1: Podatki zobniških dvojic

\begin{tabular}{|c|c|c|c|c|}
\hline & \multicolumn{2}{|c|}{ Gear pair $1,2,3$} & \multicolumn{2}{|c|}{ Gear pair 4,5} \\
\hline Parameter & Pinion & Gear & Pinion & Gear \\
\hline Module $m(\mathrm{~mm})$ & \multicolumn{2}{|r|}{4} & \multicolumn{2}{|r|}{4} \\
\hline $\begin{array}{l}\text { Centre distance } a \\
(\mathrm{~mm})\end{array}$ & \multicolumn{2}{|c|}{80} & \multicolumn{2}{|c|}{100} \\
\hline Pressure angle $\alpha\left(^{\circ}\right)$ & \multicolumn{2}{|c|}{25} & \multicolumn{2}{|c|}{20} \\
\hline Width $b(\mathrm{~mm})$ & 25 & 25 & 25 & 25 \\
\hline Number of teeth $z(-)$ & 9 & 31 & 23 & 27 \\
\hline Profile shift $x(\mathrm{~mm})$ & 0.4871 & -0.4871 & 0 & 0 \\
\hline $\begin{array}{l}\text { Addendum height } h_{\mathrm{aP}} \\
(\mathrm{mm})\end{array}$ & 4.750 & 2.000 & 4 & 4 \\
\hline $\begin{array}{l}\text { Dedendum Height } h_{\mathrm{fP}} \\
(\mathrm{mm})\end{array}$ & 3.051 & 6.949 & 5 & 5 \\
\hline $\begin{array}{l}\text { Root radius profile } \rho \\
(\mathrm{mm})\end{array}$ & 1.24 & 48 & 1.83 & 1.78 \\
\hline Material & POM & 42CrMo4 & $\begin{array}{l}\text { POM/ } \\
\text { PA }\end{array}$ & 42CrMo4 \\
\hline $\begin{array}{l}\text { Young's modulus } E \\
\text { (MPa) }\end{array}$ & 560 & 206000 & $\begin{array}{l}560 / \\
3000\end{array}$ & 206000 \\
\hline Poisson's ratio $v(-)$ & 0.35 & 0.33 & $\begin{array}{l}0.35 / \\
0.35\end{array}$ & 0.33 \\
\hline
\end{tabular}

The computational results based on the numerical procedure as described above have then been used to determine the appropriate mathematical formulation where the tooth tip deflection $\lambda$ is expressed according to the Young's modulus of the coating material $E$ and the coating thickness $t$. Several forms of polynomials were used to find the best fit, however the best correlation was found using the following Equation (4):

$$
\lambda=A+B \cdot E+C \cdot t+D \cdot \ln t+F \cdot \ln E
$$

The computational parameters $A, B, C, D$ and $F$ were calculated using the least squares method. The large value of the coating material's Young's modulus and large coating thickness cause a minimum deflection $\lambda$, and vice versa. This fact can lead to verification of the model and the derivation of extreme values. Using the global optimization method, the coating material Young's modulus $E$ and coating thickness $t$ parameters were determined, yielding the minimum and maximum deflections. Equation (4) is valid for general nonlinear elastic base materials.

\section{COMPUTATIONAL RESULTS}

As described in section 2, the computational analysis of a gear without coating has been carried out first to compare the numerical results with the results of the analytical procedure as described in VDI 2736. ${ }^{15}$ The first finite element analysis (FE-E model) using the standard Young's modulus and with torque $T=10 \mathrm{Nm}$ (tangential force $F_{\mathrm{t}}=555.6 \mathrm{~N}$ ) results in a tooth tip deflection of the uncoated pinion $=0.388 \mathrm{~mm}$, while the standardised VDI calculation gives a value $\lambda=0.361$ $\mathrm{mm}$. Using a modified computational model (FE-HE model), the tooth tip deflections are also determined for coated gears with different Young's modulii of coating materials and constant coating thickness $t=0.1 \mathrm{~mm}$. As shown in Figure 3, the tooth tip deflection of the coated pinon is reduced compared to the tooth tip deflection of an uncoated gear and is for a tangential force, $F_{\mathrm{t}}=555.6$ $\mathrm{N}$, inside the permissible limit according to VDI 2736 . It is evident from Figure 4 that a reasonably thick coating of $t=0.1 \mathrm{~mm}$ can have a significant influence on the deflection values of polymer gears.

Combining the computational results with Equation (4), valid parameters for treated Gear pair 1 with regression $R=0.991$ are determined:

$A=0.5173140, B=8.42502 \cdot 10^{-8}, C=-0.236158, D$ $=0.000644889$ and $F=-0.0251878$.

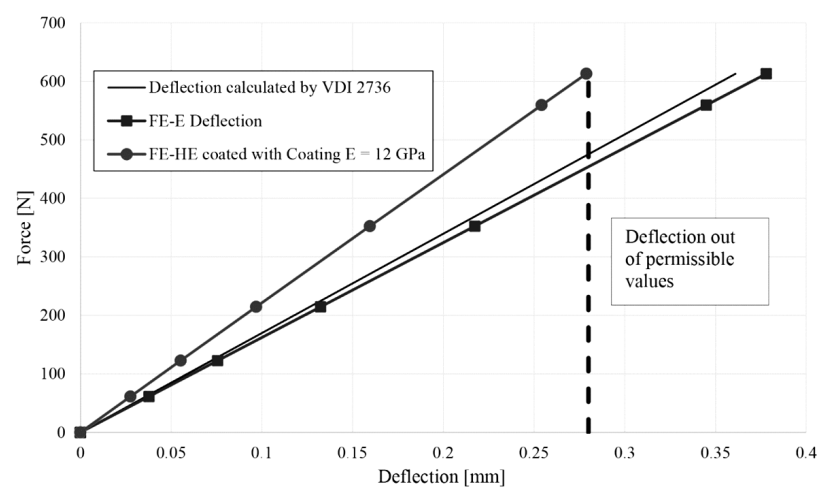

Figure 4: Comparison of gear tooth tip deflection with and without coating (Gear pair 1)

Slika 4: Primerjava povesa vrha zoba zobnika $\mathrm{z}$ in brez prevleke (zobniška dvojica 1)

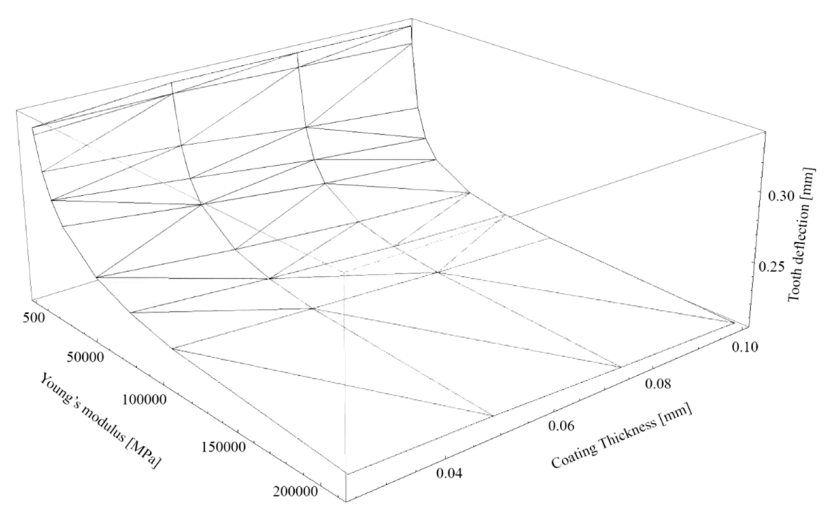

Figure 5: The effect of Young's modulus and coating thickness on the tooth tip deflection for gear pair 1 and $R=0.991$

Slika 5: Vpliv modula elastičnosti in debeline prevleke na poves vrha zoba za zobniško dvojico 1 in $R=0,991$ 


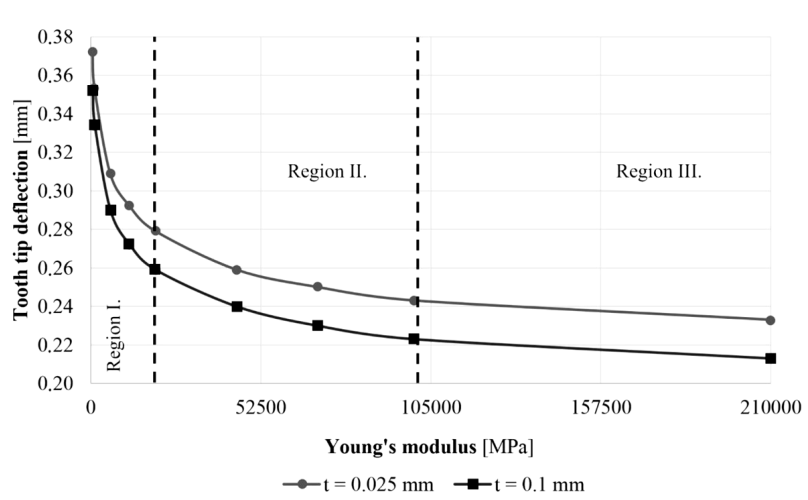

Figure 6: Comparison of tooth tip deflection for two coating thicknesses on gear pair 1

Slika 6: Primerjava povesa vrha zoba za dve debelini prevlek na zobniški dvojici 1

For different gear pairs we obtained the coefficients $A, B, C, D, F$ (Table 3) and with different regression values $R$ which can be found in Table 2. The effect of the Young's modulus $E$ and coating thickness $t$ on the tooth tip deflection according to Equation (4) is presented in Figure 5. The minimum tooth tip deflection $\lambda_{\min }=0.2132 \mathrm{~mm}$ is observed for Young's modulus $E=$ $210 \mathrm{GPa}$ and a coating thickness $t=0.1 \mathrm{~mm}$, with the maximum tooth tip deflection $\lambda_{\max }=0.3717 \mathrm{~mm}$ seen for Young's modulus is $E=560 \mathrm{MPa}$ and coating thickness $t$ $=0.025 \mathrm{~mm}$.

The influence of Young's modulus on the tooth tip deflection for minimum $(t=0.025 \mathrm{~mm})$ and maximum $(t=0.1 \mathrm{~mm})$ coating thicknesses is presented in Figure 6. In region I it can be seen that an increase of the Young's modulus of the surface coating can significantly reduce the tooth tip deflection of the treated gear (about $26.4 \%$ relative to that of Young's modulus $E=560 \mathrm{MPa}$ and $E=$ $20000 \mathrm{MPa}$ ). A somewhat smaller decrease of the tooth tip deflection with increase of Young's modulus is observed in region II (about $13 \%$ relative to that of at $E=20000 \mathrm{MPa}$ and $E=105000 \mathrm{MPa}$ ), while in region III the toot tip deflection drops only about $6.1 \%$.

Similar results to those described above are also found when the tooth tip deflection is studied for two given Young's modulii (560 $\mathrm{MPa}$ and $210 \mathrm{GPa}$ ) and different surface coating thickness (Figure 7). For uncoated gears $(t=0)$ a tooth tip deflection of $0.388 \mathrm{~mm}$ is observed. When a surface coating is applied, the significant drop of tooth tip deflection is observed especially for harder surface coatings. In region I (up to coating thickness of $0.025 \mathrm{~mm}$ ) the decrease of tooth tip

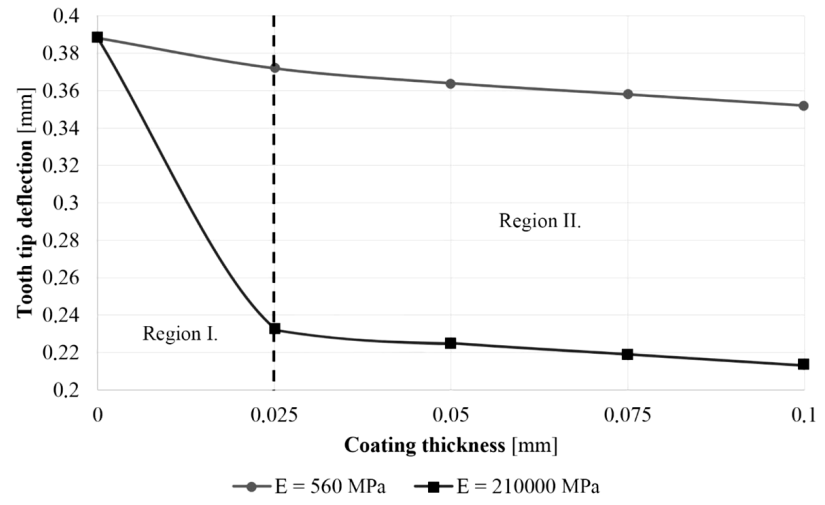

Figure 7: Comparison of tooth tip deflection for two different coating materials on gear pair 1

Slika 7: Primerjava povesa vrha zoba za dva tipa prevlek na zobniški dvojici 1

deflection is about $40 \%$, while in region II this value is only $9 \%$.

The deflection behaviour of five gear pairs was examined at the given operating conditions (Table 2). Two distinct geometries were tested with different core materials. Table 2 shows the values for regression of all five cases. The largest deflection has been found in the gear pair 1, with torque $10 \mathrm{Nm}$ and $\mathrm{POM}$ as the core material. The smallest deflection was observed in gear pair 5, with torque $10 \mathrm{Nm}$ and $\mathrm{PA}$ as a core material.

Table 2: Fitting of equation with FE values

Tabela 2: Ujemanje enačbe $\mathrm{z}$ MKE rezultati

\begin{tabular}{|c|c|c|c|}
\hline Gear & Torque $(\mathrm{Nm})$ & Material & Regression $R$ \\
\hline $\begin{array}{c}\text { Gear pair 1 } \\
i=9 / 31\end{array}$ & 10 & $\begin{array}{c}\text { Delrin 100 } \\
\text { NC010 }\end{array}$ & 0.9910 \\
\hline $\begin{array}{c}\text { Gear pair 2 } \\
i=9 / 31\end{array}$ & 5 & $\begin{array}{c}\text { Delrin 100 } \\
\text { NC010 }\end{array}$ & 0.9806 \\
\hline $\begin{array}{c}\text { Gear pair 3 } \\
i=9 / 31\end{array}$ & 1 & $\begin{array}{c}\text { Delrin 100 } \\
\text { NC010 }\end{array}$ & 0.9790 \\
\hline $\begin{array}{c}\text { Gear pair 4 } \\
i=23 / 27\end{array}$ & 10 & $\begin{array}{c}\text { Delrin 100 } \\
\text { NC010 }\end{array}$ & 0.9781 \\
\hline $\begin{array}{c}\text { Gear pair 5 } \\
i=23 / 27\end{array}$ & 10 & $\begin{array}{c}\text { Ultramid } \\
8202\end{array}$ & 0.9650 \\
\hline
\end{tabular}

In Table 3, the $A, B, C, D$ and $F$ coefficients are given for different gear pairs. It is evident that by reducing force or increasing the stiffness of the base material (gear pair 5), these coefficients approach zero. This is a direct consequence of the fact that the tooth tip deflection decreases with stiffer materials and/or reduced

Table 3: Equation coefficients for equation 4

Tabela 3: Koeficienti za enačbo 4

\begin{tabular}{|l|c|c|c|c|c|}
\hline \multicolumn{1}{|c|}{ Gear } & $A$ & $B$ & $C$ & $D$ \\
\hline Gear pair 1 i $=9 / 31$ & 0.5173140 & $8.42502 \mathrm{E}-08$ & -0.236158000 & 0.000644889 & -0.025187800 \\
\hline Gear pair 2 $\mathrm{i}=9 / 31$ & 0.2407840 & $3.56586 \mathrm{E}-08$ & 0.053658500 & -0.004475320 & -0.012522600 \\
\hline Gear pair 3 i $=9 / 31$ & 0.0463095 & $7.10510 \mathrm{E}-09$ & 0.000250842 & -0.001774000 & -0.002599930 \\
\hline Gear pair 4 i $=23 / 27$ & 0.1549290 & $3.23817 \mathrm{E}-08$ & -0.009230920 & -0.006828120 & -0.010816000 \\
\hline Gear pair 5 i $=23 / 27$ & 0.0304427 & $-1.67453 \mathrm{E}-08$ & -0.009067370 & -0.000983624 & -0.001365980 \\
\hline
\end{tabular}


torque. For gear pair 1 (the weakest material and the largest torque) the maximum coefficient deviations and consequently the highest tooth tip deflection was observed.

\section{CONCLUSION}

The influence of different coating materials and coating thicknesses on the tooth tip deflection of polymer gears made of POM and PA is presented in this paper. The tooth tip deflection was determined numerically using a finite element model. Here, the mechanical properties of the core material were defined using the Marlow hyperelastic material model while the coating materials' mechanical properties were defined using the linearly elastic Hooke's law. The computational results obtained have then been used to define the approximate analytical equation, where linear and logarithmic terms of Young's modulus and coating layer thickness were used. The obtained analytical equation form describes the tooth tip deflection. It is valid for coating material Young's modulii in the range from $560 \mathrm{MPa}$ to $210 \mathrm{GPa}$, coating thicknesses between $0.025 \mathrm{~mm}$ to $0.1 \mathrm{~mm}$, different loads, different nonlinear elastic base materials and different geometries. The final results showed that the use of stiff surface coatings on polymer gears significantly reduce the tooth tip deflection and consequently improve the operation of such gear pairs.

Further investigations for coated polymer gears should cover the potential cracking of hard coatings in the case where the core material stiffness is too low. The coating layer wear due to the relative sliding of gear flanks and its influence on the tooth tip deflection should also be studied. To confirm the computational results, the experimental testing of bending behaviour of coated polymer elements should be carried out.

\section{Acknowledgement}

The doctoral study of the first author is partly cofinanced by the European Union through the European Social Fund. Co-financing is carried out within the framework of the Operational Programme for Human Resources Development for the period 2007-2013, 1. Development priorities for Promoting entrepreneurship and adaptability; policy priority. 3: Scholarship Scheme. ${ }^{15-19}$

\section{REFERENCES}

${ }^{1}$ P. Wyluda, D. Wolf, Examination of finite element analysis and experimental results of quasi-statically loaded acetal copolymer gears, Axel Products, Inc., http://www.axelproducts.com/downloads/ FEA_gears_copolymer.pdf, 7.6.2016

${ }^{2}$ E. Letzelter, M. Guingand, J. P. de Vaujany, P. Schlosser, A new experimental approach for measuring thermal behaviour in the case of nylon 6/6 cylindrical gears, Polymer Testing, 29 (2010) 8, 1041-1051, doi:10.1016/j.polymertesting.2010.09.002

${ }^{3}$ C. J. Hooke, S. N. Kukureka, P. Liao, M. Rao, Y. K. Chen, The friction and wear of polymers in non-conformal contacts, Wear, 200 (1996) 1-2, 83-94, doi:10.1016/s0043-1648(96)07270-5

${ }^{4}$ D. Petrov, K. Dearn, D. Walton, R. Banks, The Influence Of Surface Coatings On The Wear Of Polyamide Gears, Proceedings of I International Conference - Process Technology And Environmental Protection (PTEP 2011), 2011, 9

${ }^{5}$ AGMA, AGMA 1006-A97: Tooth Proportions for Plastic Gears

${ }^{6}$ Cylindrical gears. Calculation of service life under variable load. Conditions for cylindrical gears in accordance with ISO 6336, BSI British Standards, doi:10.3403/01383565

${ }^{7}$ VDI, VDI 2736 Blatt 2: Thermoplastic gear wheels - Cylindrical gears - Calculation of the load-carrying capacity, Postfach 101139 , 40002 Dusseldorf

${ }^{8}$ M. Rao, C. J. Hooke, S. N. Kukureka, P. Liao, Y. K. Chen, The effect of PTFE on the friction and wear behavior of polymers in rollingsliding contact, Polymer Engineering Đ\& Science, 38 (1998) 12, 1946-1958, doi:10.1002/pen.10364

${ }^{9}$ ISO, ISO 53: Cylindrical gears for general and heavy engineering Standard basic rack tooth profile

${ }^{10}$ DuPont, DuPont Engineering Polymers, <http://plastics.dupont.com/ plastics/pdflit/americas/markets/gears.pdf $>$ (accessed 4 2015)

${ }^{11}$ V. A. Beloshenko, Y. E. Beigel'zimer, V. N. Varyukhin, Y. V. Voznyak, Strain hysteresis of polymers, Dokl Phys Chem, 409 (2006) 1, 207-209, doi:10.1134/s0012501606070086

${ }^{12}$ C. datasheet DuPont, Delrin ${ }^{\circledR} 100$ NC010 - POM DuPont Engineering Polymers, <http://www.campusplastics.com/campus/en/datasheet/Delrin\%C2\%AE+100+NC010/DuPont/52/6fc48544>, (accessed 4 2015)

${ }^{13}$ BASF, Ultramid® 8202 Polyamide 6, <http://iwww.plasticsportal. $\mathrm{com} /$ products/dspdf.php?type $=$ iso $\&$ param $=$ Ultramid $+8202>$ (accessed 6 2015)

${ }^{14}$ J. Shackelford, W. Alexander (Eds.), CRC Materials Science and Engineering Handbook, Third Edition, Informa UK Limited, doi:10.1201/9781420038408

${ }^{15}$ B. Trobentar, S. Glodež, B. Zafošnik, Gear tooth deflection of spur polymer gears, in International Gear Conference, Lyon, 2014, 129-137, doi:10.1533/9781782421955.129

${ }^{16}$ A. Version, 6.12 Documentation Collection, ABAQUS/CAE User's Manual, 2013

${ }^{17}$ A. B. Cropper, The failure mode analysis of plastic gears, University of Birmingham, 2003

${ }^{18}$ D. Petrov, K. Dearn, D. Walton, R. Banks, Some Experimental Results Concerning The Influence Of Surface Coatings On The Wear Of Poly-Ether-Ether-Ketone (PEEK) Polymeric Gears, Annals of the University Dunarea de Jos of Galati: Fascicle: VIII, Tribology, 17 (2011) 1, 5-10

${ }^{19}$ D. Petrov, K. Dearn, D. Walton, R. Bancs, Some Experimental Results Concerning The Iinfluence Of Surface Coatings From Solid Lubricants On The Wear Of Polymeric Gars, Journal of the Technical University Sofia, branch Plovdiv Fundamental Sciences and Applications Vol. 16 (2011), 6 